\title{
IMPACT THE FOLIAR APPLICATION OF SILICON AND B WITH OR WITHOUT COMPOST ON SOIL FERTILITY AND PEANUT PRODUCTIVITY UNDER NEWLY RECLAIMED SOIL CONDITIONS
}

Shaban, Kh. A. H. ${ }^{1}$; M. K. Abd el-Fattah ${ }^{2}$ and M. A. El-Galad ${ }^{1}$

${ }^{1}$ Soil, water and Environmental Res. Inst. Agric. Res. Center (ARC).Giza, Egypt

${ }^{2}$ Soil Science Dept., Faculty of Agriculture, Zagazig Univ.

Khaledshaban2004@yahoo.com

mohammedkamal8@yahoo.com

\begin{abstract}
Two field experiments were carried out in a private farm at El-Quntra Shark east Suez Canal, Egypt during the two successive summer seasons of 2011 and 2012. Both experiments were conducted to study the influence of spraying on soil surface of Silicon i.e. 0, 50, 100 and $150 \mathrm{ppm}$ and boron i.e. 0, 25, 50 and $100 \mathrm{ppm}$ with or without compost on soil fertility and yield, yield components, oil \%, protein, proline, chlorophyll content as well as nutritive status of peanut plants grown on sandy saline soil. The soil is irrigated with Sprinkler from El-Salam canal water (Nile water mixed with agriculture drainage water 1:1). The cultivar of seeds peanut was Gregory. Plant samples were taken at maturity stage to estimate the yield and the chemical composition of seeds. The results showed significant increase in all studied parameters of peanut as compared with the treatment of without compost in both seasons. The highest values of yield and yield components were obtained from plants received foliar spraying with $150 \mathrm{ppm} \mathrm{Si}$ and $100 \mathrm{ppm} \mathrm{B}$ alone or with compost. Also different rates of $\mathrm{Si}$ and $\mathrm{B}$ increased significantly the concentration of $\mathrm{N}, \mathrm{P}, \mathrm{K}, \mathrm{Si}, \mathrm{Zn}$ and $B$ in seeds of peanut in both seasons as compared without compost treatments. The highest values of $\mathrm{N}, \mathrm{P}, \mathrm{K}, \mathrm{Si}, \mathrm{Zn}$ and $\mathrm{B}$ concentrations in seeds of peanut plants were obtained by using (150 ppm of Si and $100 \mathrm{ppm}$ of B combined with compost in both seasons. The highest values of oil (\%), protein (\%) and chlorophyll contents in peanut seeds in both of seasons were attained when the highest level of Si (150 ppm) and $B(100 \mathrm{ppm})$ alone or combinated with compost. addition as foliar application. The different rates of $\mathrm{Si}$ and $\mathrm{B}$ led to decreases of proline in both seasons as compared with control. The highest values of proline in both seasons were obtained by using foliar spraying with the low rates of Si or B, under high soil salinity. Soil salinity (EC) was decrease when soil treated with compost combined with highest rates of Si 150 ppm and B 100 ppm. Soil pH decreased with increasing Si and B combined with compost.The highest values of $\mathrm{N}, \mathrm{P}, \mathrm{K}, \mathrm{Si}, \mathrm{B}$ and $\mathrm{Zn}$ were obtained from soil receiving foliar spraying with $150 \mathrm{ppm} \mathrm{Si}$ and $100 \mathrm{ppm} B$ alone or with compost.

It could be concluded that foliar spray Si and boron at (100 and $150 \mathrm{ppm} \mathrm{Si}$ ) and (50 and100 ppm B) in combination with compost led to improve soil fertility, enhanced plant growth and peanut yield and its components.
\end{abstract}

Keyword: Silicon, Boron, Peanut yield and quality, sandy saline soil. 


\section{INTRODUCTION}

Soil salinity decreases crop yield through increasing osmotic stress on the plant. Under saline conditions, nutrient imbalance, reduces nutrient uptake including $\mathrm{K}^{+}$, and ion toxicity are resulted because of high $\mathrm{Na}^{+}$and $\mathrm{Cl}$ concentrations (Miransari and Smith, 2007).

Total cultivated area in Egypt is approximately 3.15 million hectare (hectare $=2.385$ Feddan); comprised of 2.35 million hectare of old fertile soil and 0.8 million hectare of new reclaimed soil. Egypt has a rapid population growth rate, expected to reach about 85 million inhabitants by the year 2025, Hafez (2005).

The Sandy Soil which represents is 340000 feddans in east Suez Canal, (South El-Qantara and Bir El Abd) 205000 feddan. The area was planned to be irrigated by spraying and it was planed to be cultivated by $37 \%$ field crops, $22 \%$ animals food, $15 \%$ fruits crops, $14 \%$ vegetable crops, $6 \%$ olives crops and $6 \%$ oil crops. Salinity is one of the most important abiotic stresses, limiting crop production in arid and semi-arid regions, where soil salt content is naturally high and precipitation can be insufficient for leaching (Zhao et al., 2007).

Silicon ( $\mathrm{Si}$ ) is considered a beneficial element for higher plants because of both direct and indirect positive effects on growth, (Ma and Takahashi, 2002). Increasing $\mathrm{Si}$ availability in the soil is usually accompanied by increasing Si content in the plant (Korndorfer and Lepsch, 2001). Silicon can also increase the physiological availability of zinc ( $\mathrm{Zn})$ in leaf tissue (Marschner et al., 1990). Tavakkol et al. (2011) found that the silicon uptake by peanut increased by $130 \%$ at $200 \mathrm{~kg} \mathrm{Si} \mathrm{ha}^{-1}$ and $240 \%$ at $800 \mathrm{~kg} \mathrm{Si} \mathrm{ha}^{-1}$ over no Si application. Also , P auptake by plant increased up to $120 \%$ due to Si application. Biglary et al (2011) showed that chlorophyll content was increased with the application of silicon compared to the control and drought treatments. Wang and Galletta (1998) concluded that foliar spray with potassium silicate increased plant growth of straw berry. Hashemi et al., (2010) reported that salinity decreased plant growth parameters such as tissue fresh and dry weights. These decreases were accompanied by increasing lignin contents, $\mathrm{Na}+$ ion accumulation, and also increasing lipid per oxidation and decreasing chlorophyll contents in plants. Silicon nutrition, however, enhanced plant growth parameters and led to the prevention of lignin and the $\mathrm{Na}+$ accumulation in shoots, reduced levels of lipid per oxidation in the roots and higher levels of chlorophyll. Pandey and Yadav (1999) reported that spraying silicon increased grain yield/plant of wheat. They referred that to an increase in plant water status, chlorophyll content, biological yield and harvest index, coupled with reduced values of water potential, increase in dry matter accumulation, dry matter production rate, leaf area/plant at the flowering stage, productive tillers, grains and grain yield/main spike and per plant and transpiration rate coupled with a decrease in stomata conductance. Abou-Baker et al., (2011) reported that silica have a good adsorption capacity and decrease $P$ leaching by $40-70 \%$. Silicon addition may improve nutritional balance under saline soil conditions, thereby 
a better growth performance and consequence yield production was obtained. Hanafy et al., (2008) showed that silicon play an important role in improving $\mathrm{P}$ nutrition. In field experiment, silicon significantly increased $\mathrm{N}, \mathrm{P}$ and $\mathrm{K}$ concentrations in shoots as well as in grains.

Boron (B) is an essential nutrient for normal growth of higher plants and its availability in soil and irrigation water is an important determinant of agricultural production (Saleem et al., 2011). Noor et al (1997) found that the importance of application of boron led to increasing peanut yield. The $\mathrm{pH}$ is the most important factor affecting $\mathrm{B}$ adsorption in soils, with increasing soil solution $\mathrm{pH}, \mathrm{B}$ fixation also increases and maximum adsorption is near $\mathrm{pH} 8$ to 9, further increase in solution $\mathrm{pH}$ decreases the adsorption. Boron adsorption surfaces in the soil are oxides, clay minerals, calcium carbonate and organic matter (Goldberg and Chuming 2007). Nasef et al (2006) reported that spraying with the two different levels of $B$ (100 and $200 \mathrm{ppm}$ ) significantly increased of peanut, weight of 100 seeds, pods yield, yield of seeds in both season as compared with the control. On the other hand foliar spray with different levels of B, i.e. 100, 200 and 300 ppm significantly increased the uptake of $\mathrm{N}, \mathrm{P}, \mathrm{K}, \mathrm{Fe}, \mathrm{Mn}$ and $\mathrm{B}$ by straw and seeds of peanut plants grown for two successive seasons as compared with the control treatment (sprayed with tap water). Khalifa (2005) found that foliar spraying of $B$ treatments improved the nutritive status of peanut plant content of $\mathrm{Mn}, \mathrm{Zn}$ and $B$ where they increased as compared with non treated plants in two successive seasons. Rifaat et al (2004) who stated that the highest values of oil and protein contents in peanut plants were obtained with the foliar addition of $B$ at the highest concentration of $300 \mathrm{ppm} B$.

The aim of present study was to investigate the effect of silicon and Boron spraying combined with or without compost on some chemical soil properties and productivity and quality of peanut crop under sandy saline soil.

\section{MATERIALS AND METHODS}

Two field experiments were carried out in a sandy saline soil of private farm at El-Quntara Shark east Suez Canal, Egypt, during two successive seasons of summer, 2011 and 2012. Spraying of silicon on soil surface was from potassium silicate at rates $0,50,100$ and $150 \mathrm{ppm}$ and boron was from boric acid at rates $0,25,50$ and $100 \mathrm{ppm}$. The application was alone or in combination with compost to study their effect on soil fertility and peanut productivity and quality under sandy saline soil. Some chemical and physical analyses of the experimental soil are shown in Table (1).

The soils irrigated with sprinkler from El-Salam canal (Nile water mixed with Agriculture drainage water 1:1). The experimental design was a randomized complete block (RCB), treatments being replicated 3 times. The peanut variety was Gregory (Arachis hypogaea $L$ ) which obtained from Crop Institute to Agriculture Research Center, Giza, Egypt. The area of each experimental unit (plot) was $5 \times 10 \mathrm{~m}$ which divided into rows with $50 \mathrm{~cm}$. All farming processes were carried out before planting. Also, the experiment soil was divided into two parts; the First part was treated with compost at a rate of 
Shaban, Kh. A. H. et al.

5 tons per fadden while the second part without compost. Compost was plowed 25 days before peanut planting. The compost analyses were done according to the standard methods as described by Brunner and Wasmer (1978), compost alalysis source shown in Table (2).

Table (1): Some physical and chemical properties of the studied soil.

\begin{tabular}{|c|c|c|c|c|c|c|c|c|}
\hline \multirow{3}{*}{\begin{tabular}{|c|} 
Coarse \\
sand (\%)
\end{tabular}} & \multirow{2}{*}{\multicolumn{4}{|c|}{ Particle size distribution }} & & \multirow{3}{*}{\multicolumn{2}{|c|}{$\begin{array}{l}\text { O.M } \\
(\%)\end{array}$}} & \multirow[b]{3}{*}{$\begin{array}{c}\mathrm{CaCO}_{3} \\
(\%)\end{array}$} \\
\hline & & & & & & & & \\
\hline & $\begin{array}{l}\text { Fine } \\
\text { sand } \\
(\%)\end{array}$ & $\begin{array}{l}\text { Silt } \\
(\%)\end{array}$ & $\begin{array}{l}\text { Clay } \\
(\%)\end{array}$ & & & & & \\
\hline 9.70 & 81.24 & 3.99 & 5.07 & & andy & 0.5 & & 3.29 \\
\hline \multirow[b]{2}{*}{ pH (1:2:5) } & \multirow{2}{*}{$\begin{array}{l}E C \\
(\mathrm{dS} / \mathrm{m})\end{array}$} & \multicolumn{4}{|c|}{ Cations (meq/l) } & \multicolumn{3}{|c|}{ Anions (meq/l) } \\
\hline & & $\mathrm{Ca}^{++}$ & $\mathrm{Mg}^{++}$ & $\mathrm{Na}^{+}$ & $\mathrm{K}^{+}$ & $\mathrm{HCO}_{3}^{-}$ & $\mathrm{Cl}^{-}$ & $\mathrm{SO}_{4}^{--}$ \\
\hline 8.04 & 6.89 & 8.37 & 14.45 & 45.27 & 0.81 & 4.91 & 37.00 & 26.99 \\
\hline \multicolumn{3}{|c|}{$\begin{array}{c}\text { Available } \\
\text { Macronutrients (mg/kg) }\end{array}$} & \multicolumn{6}{|c|}{$\begin{array}{c}\text { Available } \\
\text { Micronutrients (mg/kg) }\end{array}$} \\
\hline $\mathbf{N}$ & $\mathbf{P}$ & $\mathbf{K}$ & B & Si & & & n & \\
\hline 32 & 2.59 & 185 & 0.79 & 15.89 & & & 79 & \\
\hline
\end{tabular}

Table (2): Chemical analysis of compost.

\begin{tabular}{|c|c|c|c|c|c|c|c|c|c|c|c|c|}
\hline \multirow{3}{*}{$\begin{array}{l}\text { Moisture } \\
\text { content \% }\end{array}$} & \multirow{3}{*}{$\begin{array}{l}\text { EC } \\
\mathrm{dSm}^{-1} \\
(1: 10)\end{array}$} & \multirow[b]{2}{*}{$\begin{array}{c}\mathrm{pH} \\
1: 2.5\end{array}$} & \multirow[b]{2}{*}{ C } & \multirow[b]{2}{*}{$\mathrm{C} / \mathrm{N}$} & \multirow[b]{2}{*}{ O.M } & $\mathrm{N}$ & $\mathbf{P}$ & $\mathrm{K}$ & $\mathrm{Fe}$ & $\mathrm{Mn}$ & $\mathrm{Zn}$ & $\mathrm{Cu}$ \\
\hline & & & & & & \multirow{2}{*}{\multicolumn{3}{|c|}{$\begin{array}{c}\text { Available } \\
\text { Macronutrients }\end{array}$}} & \multirow{2}{*}{\multicolumn{4}{|c|}{$\begin{array}{c}\text { Available } \\
\text { Micronutrients } \\
\left(\mathrm{mgkg}^{-1}\right)\end{array}$}} \\
\hline & & \multicolumn{4}{|r|}{ (\%) } & & & & & & & \\
\hline 27 & 4.21 & 7.5 & 26 & 13.9 & 35 & 1.87 & 0.86 & 1.57 & 235 & 93 & 132 & 40 \\
\hline
\end{tabular}

Super phosphate $\left(15.5 \% \mathrm{P}_{2} \mathrm{O}_{5}\right)$ was applied at rate of $100 \mathrm{~kg}^{-1} \mathrm{fed}^{-1}$ during tillage soil. Urea $(46 \% \mathrm{~N})$ was applied as N fertilizer at rate of $30 \mathrm{~kg} \mathrm{~N}^{\mathrm{fed}}$ on two equal doses after 21 and 45 days from planting. Potassium sulphate $\left(48 \% \mathrm{~K}_{2} \mathrm{O}\right.$ ) was applied at rate of $75 \mathrm{~kg} \mathrm{~K}_{2} \mathrm{O} \mathrm{fed}{ }^{-1}$ on two equal doses after 21 and 45 days from sowing.

For soil analysis, the soil surface $(0-30 \mathrm{~cm})$ sample was collected, air dried, passed through a $2 \mathrm{~mm}$ sieve and mixed thoroughly according to Piper (1950). Calcium carbonate was determined using a Calcimeter and calculated as $\mathrm{CaCO}_{3} \%$. Organic matter was measured as described by Jackson, (1976) .Total soluble salts were determined in the saturated soil paste extract according to Jackson, (1976). The $\mathrm{pH}$ was measured using a $\mathrm{pH}$ meter in soil suspension (1: 2.5) soil water (Richards, 1954). Soluble cations and anions were determined in soil paste extract according to Black (1965). Available nitrogen was measured according to the modified Kjeldahal method by Black, (1965). Available phosphorous was extracted by $0.5 \mathrm{~N}$ sodium bicarbonate and determined colorimetrically according to Olsen s' method (Jackson, 1976). The available K was determined using the flame photometer according to Soltan pour and Schwab (1977). Available micronutrients were extracted using ammonium bicarbonate + (DTPA) and determined using Inductively Coupued Plasma (ICP) Spectrometry model 400, as described by SoltanPour (1985).

Sowing was carried out in $10^{\text {th }}$ of May 2011 and $15^{\text {th }}$ of May 2012. At harvesting stage (150 days for Gregory cultivar), the plants of the other three replicates were harvested. Each fresh plant sample was separated into pods. 
Pods were air-dried and oven dried at $70 \mathrm{C}^{\circ}$ for $48 \mathrm{hrs}$. Number of branches per plant, pods $\left(\mathrm{kg} \mathrm{fed}^{-1}\right)$, seeds $\left(\mathrm{g} \mathrm{plant}^{-1}\right.$ and $\left.\mathrm{kg} \mathrm{fed}^{-1}\right)$ and weight of 100 seed $(\mathrm{g})$ were estimated. Portions of the oven-dried seeds were ground and kept in plastic bags for chemical analysis. A $0.5 \mathrm{~g}$ of each oven dried plant sample was digested using $\mathrm{H}_{2} \mathrm{SO}_{4}^{-}, \mathrm{HClO}_{4}$ mixture according to the method described by Chapman and Pratt( 1961). The plant content of N, P, K, Si , B and $\mathrm{Zn}$ were determined in plant digestion using the methods described by Jackson (1976) and Cottenie et al.(1982) and Page et al. (1982) Oil seed content was determined using Soxhlet method according to A.O.A.C. (1990) . Protein percentage of seeds was calculated by multiplying the nitrogen percentage by the factor 6.25. Photosynthetic pigments (Chlorophyll $(a, b)$ was estimated in fresh leaves as described by Witham et al.(1971). proline content was estimated according to the methods described by Bates et al., (1973).

The obtained data were statistically analyzed using the COSTAT program and L.S.D. test at the probability levels of $5 \%$ according to Gomez and Gomez (1984).

\section{RESULT AND DISCUSSION}

\section{Soil pH}

Effect of potassium silicate (source of silicon) and boric acid (source of B) on soil pH was positive under the saline soil conditions. Data in Table (3) show that the soil $\mathrm{pH}$ decrease slightly with increasing rates of $\mathrm{Si}$ or $\mathrm{B}$ sprayed alone or combined with compost. It was also found that soil $\mathrm{pH}$ tend to decrease slightly due to the application of compost. The soils of all the experimental plots were characterized by slight to moderate alkaline conditions, where the $\mathrm{pH}$ value was around 8.04-7.95. These findings are in agreement with those reported by Wahdan et al. (1999). Data present in Table (3) showed that soil pH tends to decrease slightly throughout the two season with increasing the $\mathrm{Si}$ and $\mathrm{B}$ level combined with compost; hence values of $\mathrm{pH}$ soil were ranged between 8.04 to 8.00 in the first season and 8.03 to 7.99 in second seasons without compost, while the soil pH values were ranged between 8.03 to 7.97 in the first season and 8.02 to 7.95 in the second seasons as with compost. These results are in agreement with those obtained by (Miyake and Takahashi 1983) where they found that the silicate fertilizer applications led to decrease soil pH. Raven, (1980) reported that boric acid is a very weak acid in aqueous solution: its activity as an acid appears to be related to $\mathrm{OH}$ acceptance by the $\mathrm{B}(\mathrm{OH}) 3$ rather than to $\mathrm{H}^{+}$ donation according to the following reaction:

$\mathrm{B}(\mathrm{OH})_{3}+2 \mathrm{H} 2 \mathrm{O}------>\mathrm{B}(\mathrm{OH})_{4}+\mathrm{H}_{3} \mathrm{O}+(\mathrm{pKa9}: 25)$. Thus, in neutral or slightly acid soils, commonly occurring in plant growth environments, $\mathrm{B}$ exists mainly as undissociated boric acid. Claudio, et al (2007) found that the $\mathrm{pH}$ increment depends on the soil and the Compost characteristics as well as on the dose and time of application. Increasing the period between compost application and the plantation to 30 days resulted in low soil pH values. 
Shaban, Kh. A. H. et al.

3 
Soil salinity (EC).

Soil salinity package of the chosen experimental plot units, effect of Si or B spraying with or without compost on soil salinity is given in Table (3) which revealed that silicon and boron combined with compost showed a significant positive effect on EC the sandy saline soil in the second season. The data obtained show that the studied experimental plots are generally characterized, from the salinity point of view, by the characters found in the semi-arid regions. These characters include the accumulation of salts in surface zone of the soil, mainly due to the higher evaporation process under the dry and hot climate. Application of $50 \mathrm{ppm} \mathrm{Si}$ and B $25 \mathrm{ppm}$ without compost gave the highest soil EC respectively. However the dose of (150 $\mathrm{ppm} \mathrm{Si}$ and $100 \mathrm{ppm} \mathrm{B}$ ) alone or combined with compost gave the lowest value of soil salinity 5.25 and $5.54 \mathrm{dSm}^{-1}$ for Si and B without compost, while the $B$ or Si with compost were EC values 4.30 and $4.76 \mathrm{dSm}^{-1}$, respectively. Positive effect of increasing $\mathrm{Si}$ dose on EC soil may be to role of $\mathrm{Si}$ in development soil. Treatments were effective in decreasing soil salinity since the EC values ranged between 4.52 and $5.86 \mathrm{dsm}^{-1}$ at end of the $1^{\text {st }}$ season, with a significant differences as a result of adding compost, spraying (i.e. silicon or boron) and the rates of application; where salinity decreased at a greater rate as a result of adding compost and silicon at $150-\mathrm{ppm}$. Clear from the results that the addition of silicon at a rate 150-ppm more effective than boron in reducing soil EC. These findings are in agreement with those reported by Nasef et al (2009) they found that physical properties (hydraulic conductivity, bulk density and total porosity) of salt affected soil greatly improved with compost applied. Applied compost was reduced electrical conductivity (EC) and exchangeable sodium (ESP) by over $80 \%$. Sawas et al (2009) reported that the application of $1 \mathrm{mM} \mathrm{Si}$ was inhibitory effect of salinity and lower $\mathrm{Na}$ and $\mathrm{Cl}$. Matichenkov and Bocharnikova, (2001) found that the Si substances optimize soil fertility through improved water, physical and chemical soil properties.

Available macro and micronutrients in soil after zea maize harvest .

Data in Table (3) indicate that the applied compost as well as foliar application of Si and B increased available N, P and K contents in soil as compared with treatments of without compost. Generally it is clear from the results in Table (3) that the soils treated with compost as well as foliar application $\mathrm{Si}$ and $\mathrm{B}$ contained the relatively higher values of available $\mathrm{N}, \mathrm{P}$ and $\mathrm{K}$ than soil untreated with compost. This result reflects to more enrichment in organic materials. Concerning the obtained results showed the available of $\mathrm{N}, \mathrm{P}$ and $\mathrm{K}$ increased with increasing rate of the $\mathrm{Si}$ and $\mathrm{B}$ with was added foliarls in combination with compost. The highest values of $\mathrm{N}, \mathrm{P}$ and $\mathrm{K}$ in soil were obtained by using the treatment $100 \mathrm{ppm} \mathrm{B}$ and $150 \mathrm{ppm}$ $\mathrm{Si}$ combined with compost than other treatments. These results are in agreement with Nasef et al (2009) they suggested that applied compost resulted in reduction of soil $\mathrm{pH}$ as various acids (amino acids, such as glycine and cystein as well as humic acid) or acid forming compounds and active microorganisms were released from the addition of organic materials led to increase of available nutrients in saline soil. These results are agreement with Abou-Baker et al (2011) they suggested that application of silicate can 
Shaban, Kh. A. H. et al.

increase the quantity of mobile phosphates in the soil. Silica fertilizers also have a good adsorption capacity and decrease $P$ leaching by $40-70 \%$. Matichenkov, and Kosobrukhov, (2004) indicated that the silicon (Si) is the second most abundant element of the earth surface. Soil treatment with biogeochemically active $\mathrm{Si}$ substances optimizes soil fertility through improved water, physical and chemical soil properties and maintenance of nutrients in soil.

Effect of foliar application of Si and $\mathrm{B}$ at different rates alone or combined with compost on some micronutrients in soil study.

Compost has important role in improving soil fertility. Results in Table (3) showed that compost and foliar application of $\mathrm{Si}$ or $\mathrm{B}$ had pronounced increases in soil available microelement contents ( $\mathrm{Si}, \mathrm{B}$ and $\mathrm{Zn})$. These achieved as a result of the application of compost combined with $\mathrm{Si}$ and $\mathrm{B}$ fertilizer levels during both seasons under peanut cropping. This is more related to the residual of organic compounds that are directly composed after different biochemical and chemical changes, which led to the release of more available microelements. The effect of foliar $\mathrm{Si}$ and $\mathrm{B}$ alone or combination with compost were positive significant available $\mathrm{Si}, \mathrm{B}$ and $\mathrm{Zn}$ in soil. The highest values were increase with increasing levels of $\mathrm{Si}$ and $\mathrm{B}$ alone or combined compost. On the other hand, the effect of compost and $\mathrm{Si}$ or $\mathrm{B}$ on $\mathrm{B}$ and $\mathrm{Zn}$ available in soil were significant in first seasons but were not significant in second seasons. The significant of $\mathrm{Si}$ content in soil was affected by foliar application of $\mathrm{B}$ or Si rates combined with compost. Boron availability in soil may also be influenced by soil $\mathrm{pH}$. In general, $\mathrm{B}$ becomes more available to plants with decreasing $\mathrm{pH}$. These results are agreement by Farshid, (2011) who showed that soil acidity $(\mathrm{pH})$ influences the availability of $\mathrm{Zn}$ more than any other factor, with lower $\mathrm{Zn}$ solubility as the $\mathrm{pH}$ increases.

Macronutrient contents in seeds of peanut.

Effect of foliar application with $\mathrm{Si}$ and B on macronutrients content in seed peanut presented in Table (4). Shown that foliar application with different rates of $\mathrm{Si}(50,100$ and $150 \mathrm{ppm})$ and $\mathrm{B}(25,50$ and $100 \mathrm{ppm})$ were increased positive the concentrations of $\mathrm{N}, \mathrm{P}$ and $\mathrm{K}$. the highest values of $\mathrm{N}$, $\mathrm{P}$ and $\mathrm{K}$ concentration in seed peanut plant were with increasing rates of foliar application Si or B combined with compost than the other treatment. On the other hand, there were no significantly differences in $N, P$ and $K$ concentrations in seeds for second seasons. The relative increase in mean values of $\mathrm{N}, \mathrm{P}$ and $\mathrm{K}$ concentrations in seeds of peanut plant were $1.47 \%$ in first and $2.70 \%$ in second seasons for $\mathrm{N} ; 8.18 \%$ in first seasons and 26.47 $\%$ in second season for $\mathrm{P}$ and $1.97 \%$ in first season and $1.20 \%$ for $\mathrm{K}$ as affected with foliar application $\mathrm{Si}$ rates with compost that without compost respectively. Concerning the relative increase of mean values of $\mathrm{N}, \mathrm{P}$ and $\mathrm{K}$ as affected by $\mathrm{B}$ rates with compost than without compost were $3.98 \%$ in first season and $3.32 \%$ in second season for $\mathrm{N} ; 15.55 \%$ in first season and $14.28 \%$ in second season for $\mathrm{P}$ and $7.20 \%$ in first season and $6.67 \%$ in second season for $\mathrm{K}$ concentration in seeds peanut plant, respectively. These results are agreement by Abou Baker et al. (2011) indicated that the silica fertilizers also have a good adsorption capacity and decrease $P$ leaching by $40-70 \%$. Nasef et al (2006) Found that foliar spray with different levels of B, 
i.e. 100,200 and 300 ppm significantly increased the uptake of N, P and K by straw and seeds of peanut plants grown for two successive seasons as compared with control treatment. Silicon can directly or indirectly affect other elements absorption in plants. Gharib and Hanafy (2005) noted that, silicon foliar applications enhanced $\mathrm{N}$ and $\mathrm{K}$ concentrations in pea shoots. Berthelsen et al., (1999) showed that silicon is playing an important role in improving $P$ nutrition. Silicon significantly increased $N, P$ and $K$ concentrations in shoots as well as in grains.

Micronutrients concentrations in seeds of peanut plants.

Effect of foliar application with $\mathrm{Si}$ and B combined with or without compost positive effect on concentration of $\mathrm{Si}, \mathrm{B}$ and $\mathrm{Zn}$ in seeds peanut plant. Results in Table (4) show that foliar application with Si rates (50, 100 and $150 \mathrm{ppm})$ alone or combined with compost was significantly increased $\mathrm{Si}, \mathrm{B}$ and $\mathrm{Zn}$ in seeds of peanut plant in both seasons, compared with control un treated. The highest values of $\mathrm{Si}, \mathrm{B}$ and $\mathrm{Zn}$ concentrations in seeds in both seasons were obtained by using foliar spraying with $150 \mathrm{ppm} \mathrm{Si}$ and $100 \mathrm{ppm} \mathrm{B}$ alone or with compost compared with other treatments, respectively. Corresponding relative increases as mean values of $\mathrm{B}, \mathrm{Si}$ and $\mathrm{Zn}$ concentration in seeds peanut plant as affected by foliar application of $\mathrm{Si}$ at different rates combined with compost were $6.22 \%$ in first season and $5.70 \%$ in second season for B ; $7.64 \%$ in first season $7.50 \%$ in second for Si and $7.20 \%$ in first season and $4.13 \%$ in second season for $\mathrm{Zn}$, compared with treatments without compost respectively These results are agreement with Korndorfer and Lepsch, (2001) and Tavakkol et al. (2011). On the other hand the relative increases as mean values of $\mathrm{B}, \mathrm{Si}$ and $\mathrm{Zn}$ concentration in seeds peanut plant as affected by foliar application of $B$ different rates combined with compost were $2.42 \%$ in first season $11.45 \%$ in second season for B ; 0.68 $\%$ in first season and 2.64 in second season for $\mathrm{Si}$ and $24.42 \%$ in first season and $22.90 \%$ in second season for $\mathrm{Zn}$ compared treatments without compost respectively. These results are in agreement by Helmy and shaban (2007) showed that addition of potassium and the foliar spraying with $\mathrm{Zn}$ or B and their combinations significantly increased B- uptake by hay and seeds. The greatest $\mathrm{Zn}$ uptake by seeds and hay was occurred with the $\mathrm{K}$ application in combination with $\mathrm{Zn}+\mathrm{B}$. Jiang et al. (1995) who stated that the concentration of $B$ in groundnut plants increased with increasing $B$ fertilizer rate. Shaaban et al (2004) found that boron foliar application leads to significant increase in both concentration and uptake of $\mathrm{K}$ and $\mathrm{Zn}$ in cotton. Ahmed et al (2008) reported that boron foliar application increased uptake and concentration of nutrients in wheat leaves.

\section{Effect of the adedd treatments on protein (\%) and oil (\%) in seeds of peanut plants.}

Data presented in Table (4) show that effect of $\mathrm{Si}$ and B foliar application on protein (\%) content in seeds peanut was positive effect. Results presented in Table (4) show that effect of different rates of Si and B as foliar application alone or combined with compost on protein (\%) content in seeds of peanut plant was significant in the first season but not significant in the second one. 
Shaban, Kh. A. H. et al.

4 
The highest values of protein (\%) was $22.06 \%$ as affect by Si foliar application at rate $(150 \mathrm{ppm})$ alone, while $\mathrm{Si}$ foliar application at rate (150 $\mathrm{ppm}$ ) combined with compost the highest value of $22.25 \%$ for protein $(\%)$. The relative increases as mean values protein (\%) content in seeds peanut plant as affected foliar application different rates Si combination with compost were $1.41 \%$ in first season and $2.86 \%$ in second season compared with $\mathrm{Si}$ without compost respectively. The relative increases of mean values of protein content in seeds peanut plant as affected foliar application B different rates combined with compost were $3.92 \%$ in first season and 2.90 $\%$ in second season. On the other hand, the increases of rates for Si and B application at (150 ppm for $\mathrm{Si}$ and $100 \mathrm{ppm}$ for B) alone or combined with compost led to increase protein (\%) content in seeds peanut plant.

Also, the effect of Si and B combination with or without compost on oil (\%) content in seeds peanut plants was significant in first season. Data in Table (4) show that oil (\%) had progressive increase with increasing Si and B rates. Hence the highest oil (\%) in seeds peanut plants in two seasons were attained when the highest level of Si (150 ppm ) and B (100 ppm). These results are in agreement with Khalifa (2005) who stated that the highest values of oil and protein contents in peanut plants were obtained with the foliar addition of $B$ at the highest concentration of $300 \mathrm{ppm}$. Nasef et al (2006) indicated that the effect of spraying with $B$ may be attributed to the role of $B$ element on fundamental metabolic reactions and acceleration protein synthesis, also $B$ is involved in a number of metabolic pathways (sugar transport, respiration, carbohydrate, RNA, IAA and phenol metabolism or a cascade effect which is known for photohormones.

\section{Effect of $\mathrm{Si}$ and $\mathrm{B}$ foliar application alone or in combination with compost and without compost on yield and yield component of peanut crop.}

The compost can play an important role in improving soil fertility and plant production. Results in Table (5) show that the experimental pilot unit treated with compost significantly increased all studied parameters of peanut yield as compared without compost. Also the combined effect of foliar application with three rates i.e. $(0,50,100$ and $150 \mathrm{ppm}$ Si with compost had the same significantly positive effect on increasing weight seed/plant, weight of seed yield $\mathrm{kg} / \mathrm{fed}$ weight of 100 seed $(\mathrm{g})$, weight pod $\mathrm{kg} / \mathrm{fed}$ of peanut compared with other treatments. The relative increase of the mean values of No. of branches / plant $20 \%$ and $22 \%$; for weight seed /plant (g) 7.00 and $10.57 \%$; for weight seed yield (kg/fed) 7.95 and $7.84 \%$; for weight of 100 seeds (g) 9.40 and $9.50 \%$ and for weight pod yield $\mathrm{kg} / \mathrm{fed} 3.00$ and $2.50 \%$ in first and second season, respectively as affected of foliar application of $\mathrm{Si}$ combined with compost compared with foliar Si alone without compost. Concerning the relative increases of mean values as affect foliar application of B combined with compost were 41.20 and $25.00 \%$ for No. of branches / plant; 7.10 and $22.10 \%$ for weight seed /plant (g); 4.10 and 5.03 $\%$ for weight seed yield (kg/fed); 2.20 and $0.71 \%$ for weight of 100 seeds $(\mathrm{g})$ and 5.33 and $4.11 \%$ for weight pod yield $\mathrm{kg} / \mathrm{fed}$ in first and second season, respectively. 
Shaban, Kh. A. H. et al.

5 
The highest rate of silicon application $\left(150 \mathrm{ppm} \mathrm{SiO}_{2}\right)$ resulted in pronounced increase on all the studied yield components of peanut, especially at the soil treated with compost and the same high rate $(100 \mathrm{ppm} \mathrm{B})$ combined with compost. These results are in agreement with Hanfy et al (2008) They reported that, the highest rate of silicon application $\left(1000 \mathrm{ppm} \mathrm{SiO}_{2}\right)$ resulted in pronounced increase in all of the studied growth characters and all yield components of wheat, especially at the highest level of soil salinity (6000 $\mathrm{ppm})$, but not at the lower rate of silicon (500 ppm $\left.\mathrm{SiO}_{2}\right)$. Moreover, Liang et al. (1996) found that silicon application increase photosynthesis and decrease the permeability of plasma membranes of leaves of salt stressed barley. They also mentioned that silicon could inhibit the uptake of $\mathrm{Na}$ and increase the uptake of $\mathrm{K}$, thus mitigating salt toxicity to the plants and improving the vegetative growth of salt stressed. Nasef et al (2006) reported that spraying with the two different levels of B (100 and $200 \mathrm{ppm}$ ) significantly increased weight of 100 seeds, pods yield, yield of seeds of peanut, in both seasons as compared with the control.

So, it could be concluded that seed yield and pod yield was clearly affected by the foliar application of Si combination with compost compared with B foliar combined with compost.

\section{Effect of Si and B added spraying on Chlorophyll and Proline content in peanut plants.}

Data presented in Table (5) show the effects of Si and B added foliarly at different rates in combination with or without compost in the two successive seasons. The increase in rates of applied $\mathrm{Si}$ and $\mathrm{B}$ led to increases in chlorophyll compared with no treated plots. Total chlorophyll content increased due to Si foliar application either alone or in combined with compost than other treatments. Data in Table (5) indicate that, significant increase of these leaf pigments content Chlorophyll $a+b$ in second season was found with the increase of foliar application $\mathrm{Si}$ or B combined with compost. These results are due to the impact of $\mathrm{Si}$ and $\mathrm{B}$ combined compost used and decrease of soil salinity. These results are in agreement with Hammad et al (2010) they indicated that decrease of concentration chlorophyll $a+b$ with increasing of soil salinity. This decrease may be due to the inhibitory effect of chloride on activity of $\mathrm{Fe}$ containing enzyme, cytochrome oxidase which in turn may decrease the rate of chlorophyll biosynthesis. The relative increases of mean values for chlorophyll $a+b$ as affected Si foliar application at different rates were $8.33 \%$ in first season and $7.04 \%$ in second season compared with without compost respectively. On the other hand the relative increases of mean values for chlorophyll $a+b$ as affected by B foliar application at different rates combined with compost was $7.21 \%$ in first season and $6.77 \%$ in second season than treatments without compost. The results indicated that the increase of relative increase for mean values as affected by $\mathrm{Si}$ and $\mathrm{B}$ at different rates led to increase chorphyll $\mathrm{a}+\mathrm{b}$ content in first season than second season. Si amendment also plays a pivotal role stress and enhances chlorophyll content. Supplementation increased both $\mathrm{Chl} a$ and $\mathrm{Chl} b$ under salt stress after 10 days of $\mathrm{Si}$ application and enhanced the photochemical, (Anser et al (2012). Matichenkov and Kosobrukhov (2004) reported that the adding of Si to the 
soil resulted in increasing rate of photosynthesis from 158 to $520 \%$ depending on salt concentration in the soil. Chlorophyll fluorescence analysis and model parameters of photosynthesis indicated that $\mathrm{Si}$ enhances photochemical efficiency.

Concerning, the effect of $\mathrm{Si}$ and $\mathrm{B}$ foliar application at different rates alone or with compost on prolien content in peanut plant was positive. Data presented in Table (5) Show that the prolien content in peanut plants in both seasons significantly decreased by increasing foliar spraying rates with $\mathrm{Si}$ and $\mathrm{B}$ alone or combined with compost. Moreover, the highest prolien in peanut in both season were attained when the decrease rates of $\mathrm{Si}$ and $\mathrm{B}$. The proline concentration was significantly increased with increasing soil salinity. These results are in agreement by Hammad et al (2010) they found that the total free amino acid and proline concentrations were significantly increased with increasing salinity levels in both season. Corresponding, relative decreases of mean values proline concentration in peanut plants as affected by $\mathrm{Si}$ foliar application different rates combination with compost was $2.00 \%$ in first season and $0.78 \%$ in second season compared without compost. On the other hand the relative decreases of mean values of proline content in peanut plants as affected by $\mathrm{B}$ foliar application at different rates in combined with compost was $6.30 \%$ in first season and $6.32 \%$ in second season as compared with treatment of without compost, respectively.

From the above results it could be concluded that foliar application of silicon (source is silicate potassium) at rates of (100 and $150 \mathrm{ppm} \mathrm{Si}$ ) and boron (source is boric acid) at rates of (50 and $100 \mathrm{ppm} \mathrm{B)} \mathrm{combination} \mathrm{with}$ compost could improve some chemical properties of soil, the growth of peanut plots and reducing environmental pollution under saline soil conditions .

\section{REFERENCES}

Abou-Baker, N. H. ; Abd-El-Adl, M. and Mohsen, M. A. (2011). Effect of silicate and different cultivation practices in alleviating salts effecte on bean plants. Aust J. Basic and Applied Sci, 5(9): 769-781.

Ahmed, A. H. , Harb, E. M. , Higazy, M.A. and Morgan, S. H. (2008). Effect of silicon and boron foliar application on wheat plants grown under saline soil conditions. Int. J. Agric. Res., (3): $1-26$.

A.O.A.C., (1990). Official Methods of the Association of Official Analysis Chemists (K. Helssch, ed) A.O.A.C. Inc., 15th . Edition, Virginia, U.S.A 9- 64.

Anser , A. , Shahzad, M. A , Basra, S. Safdar, H , Javaid, I. , Ahmed, A. and Muhammad, S. (2012). Salt stress alleviation in field crops through nutritional supplementation of silicon. Pakistan .J. nutrition. 11 (8) : 637 -655 .

Bates, L.S., Waldren, R.P. and Teare, I.D. (1973). Rapid determination of free proline under water stress studies. Plant and Soil, 39: 205-207. 
Berthelsen, S., Noble, A.D. and Garside, A.L. (1999). An assessment of soil and plant silicon levels in North Queensland. In: Proceedings Australian Society of Sugar Cane Technologists, 21: 92-100.

Biglary, F.; Haddsad, R. ; Hosseini , R. and Sotudehniya, A. (2011). Roles of silicon in improving oxidative stress resistance by increase of chlorophyll content and relative water content of rice (Oryza sativa L.) genotypes. Proceedings of the $5^{\text {th }}$ International Conference on Silicon in Agriculture. September 13-18. Beijing. China.

Black , C.A. (Ed) (1965). Methods of Soil Analysis. Sei. Agron. No 9 Amer. Soc. Agron., Madison, Wisconsin.

Brunner , P. H. and Wasmer , H. R. (1978) Methods of Analysis of Sewage Sludge Solid Wastes and Compost . W.H.O . International Reference Center for Wastes Disposal ( $\mathrm{H}-8600)$, Dulendrof Switzerland.

Cláudio P. J'; Clésia C. N; Renildes L. F. ; Paulo R. C. and José L. P. (2007). Effects of composted urban solid waste addition on yield and metal contents of lettuce. J. Brazil Chem Soci.18 (1):195- 204.

Chapman, H.D. and Pratt, P.F. (1961), Methods of Analysis for Soils, Plants and Water. Agric. Publ. Univ., of California, Reverside.

Cottenie, A.; verloo, M.; Velghe, G. and Cameriynck, R. (1982). "Chemical Analysis of Plant and Soil." Laboratory of Analytical and Agrochemistry, State Univ., Ghent , Belgium.

Farshid, A. (2011). Influence of $\mathrm{Zn}$ and Boron nutrition on Copper, Manganese and Iron concentrations in Maize leaf. J. Aust. Basic and Appl. Sci. 5 (7): $52-62$.

Gharib, A.A. and Hanafy, A. H. (2005). Response of pea plants (Pisum sativum L.) to foliar application of putrescine, glucose, foliafeed $D$ and silicon. Journal of Agriculture Science Mansoura University, (30): 75637579.

Goldberg S. and Chuming, S. (2007). New advances in boron soil chemistry. F. Xu et al (ed.) Advances in Plant and Animal Boron Nutrition, 313330 Springer Science- Business Media B.V, Netherlands.

Jiang, R.F., Zhang, Q.G. , Han, L.F. Zhang, F.S. and Wei, X.Q. (1994). Effect of boric fertilizer on peanut absorption of boron and nitrogen. J. Chinese Soils. 26 (2): 83-86.

Gomez, K.A. and Gomez, A.A. (1984). Statistical Procedures of Agricultural Research. 2Ed. Wielly inter Science Publ. John Wiley and Sons. New York, 357-423.

Hafez, A. (2005).Investigation of El-Salam canal project in northern Sinai, Egypt. Ninth International Technology Conference, IWTC9, Sharm ElSheikh, Egypt, 953.

Hammad, S. A. ; Shaban, Kh. A. and Tantawy, M. F. (2010). Studies on salinity tolerance of two peanut cultivars in relation to growth, leaf water content. Some chemical aspects and yield. J. Appl. Sci. Res. 6 (10) : $1517-1526$.

Hanafy A.H.; Harb, E.M. ; Higazy M.A. and Morgan, Sh.H. (2008). Effect of Silicon and Boron Foliar Applications on Wheat Plants Grown under Saline Soil Conditions. Intern. J. Agric. Res, 3(1): 1-26. 
Hashemi, A.; Abdolzadeh, A. and Sadeghipour, H.R. (2010). Beneficial effects of silicon nutrition in alleviating salinity stress in hydroponically grown canola (Brassica napus L.), plants. Soil Sci and Plant Nutr., 56(2): 244-253.

Helmy , A. M. and Shaban, Kh. A. (2007) . Response of peanut to K fertilization and Foliar spraying with Zinc and boron under sandy doil conditions. Zagazig J. Agric. Res. 34 (4): 737 - 752.

Jackson, M. L(1976). "Soil Chemical Analysis." Constable and Co. L.T.P., London, England.

Jiang, R.F., Zhang, Q.G. , Han, L.F., Zhang, F.S. and Wei, X.Q. (1995). Effect of boric fertilizer on peanut absorption of boron and nitrogen. (Chinese) Soils. 26:2, 83-86

Khalifa, R.Kh.M., (2005). Response of peanut plants to foliar nutrition with some micronutrients. Egypt. J.Appl. Sci.; 20(1)

Korndorfer, G. H., and Lepsch, L. (2001). Effect of silicon on plant growth and crop yield. In Silicon in Agriculture, ed. L. E. Datnoff, G. H. Snyder, and G. H. Korndorfer, 133-147. Amsterdam, the Netherlands: Elsevier Science.

Liang, Y., Shen, Q. Shen, Z. and Ma, T. (1996) . Effects of silicon on salinity tolerance of two barley cultivars. J. Plant Nutr., 19: 173-183.

Ma, J. F., and Takahashi, E.. (2002). Soil, fertilizer, and plant silicon research in Japan. Amsterdam, the Netherlands: Elsevier Science , 17- 37.

Marschner, H.; Oberle, H.; Cakmak, I. and Römheld, V.( 1990). Growth enhancement by silicon in cucumber (Cucumis sativus) plants depends on imbalance in phosphorus and zinc supply. Plant and Soil 124:211219.

Matichenkov, V.V. and Bocharnikova, E. A. (2001). The relationship between silicon and soil physical and chemical properties. J. Plant Sci . (8): 209 $-219$.

Matichenkov, V. V. and Kosobraukhov, A. A. (2004). Silicon effect on the plant resistance to salt toxicity. International Soil Conserrvation Organisation Conference- $13^{\text {th }}-$ Brisban, July. Conserving Soil and Water for Society : 626- 630.

Miyake, Y. and Takahashi, E. (1983). Effects of silicon on the growth of cucumber plant in soil culture. Soil Sci and Plant Nutr.29(4):463-471.

Miransari, M and Smith, D. L. (2007). Overcoming the stressful effects of salinity and acidity on soybean [Glycine max (L.) Merr.] nodulation and yields using signal molecule geniste in under field conditions. J. Plant Nutr. 30: 1967-92.

Nasef, M. A., Badran, M. and Abd- El-Hamide, A. (2006). Response of peanut to foliar spray with and or rhizobium inoculation. J. Appl. Sci. Res. 2 (12): $1330-1337$.

Nasef, M. A.; Shaban, Kh. A. and Amal, A. (2009). Effect of compost, compost tea and bio-fertilizer application on some chemical soil properties and rice productivity under saline soil condition. J. Agric.Sci. Mansoura. Univ., 34 (4): 2609- 2623. 
Noor, S.; Hannan, M.A. and Islam, M.S. ( 1997). Effect of molybdenum and boron on the growth and yield of groundnut. Indian J. of Agric. Res., 31: 51-58.

Page, A.L; Miller, R.H. and Keeney, D.R. (1982) "Methods of Chemical Analysis". Part 2: Chemical and Microbiological Properties (2 Edition). American Society of Agronomy, Inc. and Sci. Soc. of America, Inc. Publishers, Madison, Wisconsin U.S.A.

Pandey, A.K. and Yadav, R.S. (1999). Effect of antitranspirants on phonological traits and yield of wheat under deficit conditions. Indian $\mathrm{J}$. of Agric. Res., 33: 159-164.

Piper, C. S.( 1950) " Soil and Plant Analysis." Inter. Sci . Publishers. Inc., New York.

Rashid, A. and Ryan, J. (2004). Micronutrients constraints to crop production in soils with Mediterranean -type characteristics: a review. J. Plant Nutr. 27 (6): 959 - 975

Raven J.A. (1980) Short- and long-distance transport of boric acid in plants. New Phytol. 84, 231-249.

Richards, L.A. (1954). Diagnosis and Improvement of Saline and Alkali Soils. U.S. Salinity Laboratory Staff. Agriculture Handbook, No.60.

Rifaat, M.G.M.; El-Basioni, S.M. and Hassan, H.M. (2004). Zinc and boron for groundnut production grown on sandy soil. Zagazig J. Agric. Res., 31(1): $139-164$

Saleem, M.; Khanif, Y.M.; Ishak, F.; Samsuri, A.W. and Hafeez, B. (2011) Importance of Boron for Agriculture Productivity: A Review. Intr. Res. J. Agric. Sci., 1(8): 293-300.

Sawas D. , Giotis D. , Chatzieustratiou E. , Bakes M. and Patakioutas G. (2009). Sillicon supply in soiless cultivations of zucchini alleviates stress induced by salinity and powdery mildew infections. J. Envir and Expe. Botany. 65 (1): $11-17$.

Shaaban , M. M ., El-Fouly , M. M. and Abd El-Maguid, A. A. (2004). Zinc Boron relationship in wheat plants grown under low or high levels of calcium carbonate in the soil. Pakistan J. Biol. Sci. (7): $633-639$.

Soltan Pour, N. and Schwab, A.P. (1977). A new soil test for simultaneous extraction of macro and micronutrients in alkaline soils. Commun. Soil Sci. plant Anal., 3: 195.

Soltanpour,N. (1985). Use of ammonium bicarbonate- DTPA soil test to evaluate element availability and toxicity. Soil Sci . Plant Anal. , 16 (3) : $323-338$.

Tavakkol, E.; peter, E. and Chris, N. (2011). Interaction of silicon and phosphorus mitigate manganese toxicity in rice in highly weathered soil. Commun in Soil Sci and Plant Analy., 42:503-513 .

Wahdan .A.A ; El- Gendi .S.A and Abd El-Mawgoud .A.S (1999)

Amelioration techniques for sodic soils in Al-Fayoum Oasis . Egypt .J. Soil Sci ., 39. (2) : $199-210$.

Wang, S.Y. and G.J. Galletta, (1998). Foliar application of potassium silicate induces metabolic changes in strawberry plants. J. Plant Nutr., 21(1): 157-167. 
Witham, F.H., Blaydes, D.F. and Devin, P.M. (1971). Experiments In Plant Physiology. Van Nosland Reihold. Co. New York, 55-58.

Zhao, J.; Ren, W.; Zhi, D.; Wang, L. and Xia, G. (2007). Arabidopsis DREB1A/CBF3 bestowed transgenic tall rescue increased tolerance to drought stress. Plant Cell Rep., (26), 1521-1528.

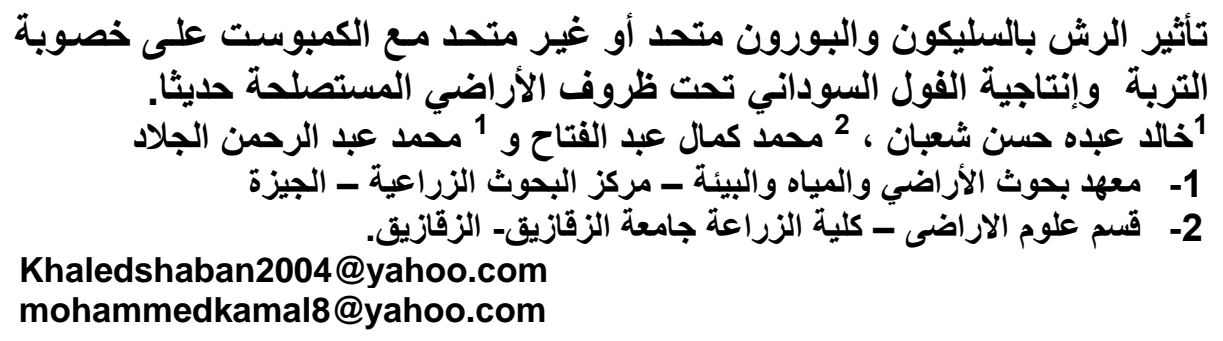

Khaledshaban2004@yahoo.com

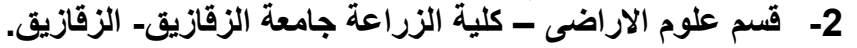
mohammedkamal8@yahoo.com

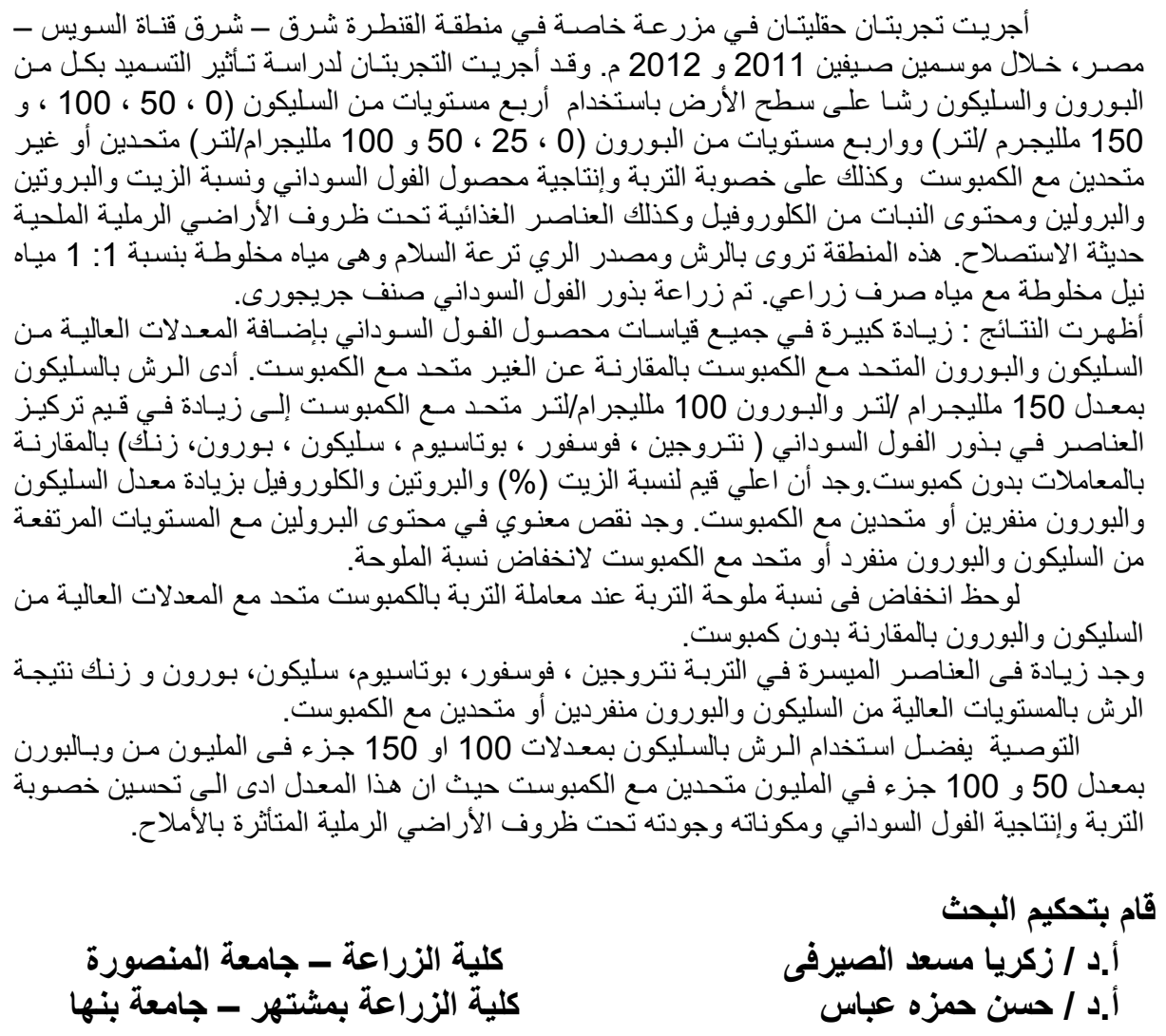


Table 3. Some soil chemical properties after harvesting of peanut (Aracnis hypogaco $\mathrm{L}$ ) during two seasons

\begin{tabular}{|c|c|c|c|c|c|c|c|c|c|c|c|c|c|c|c|c|c|c|}
\hline \multirow{2}{*}{${ }_{\text {ost }}^{\text {Comp- }}$} & \multirow{2}{*}{ Spray- } & \multirow{2}{*}{$\begin{array}{c}\text { Rate } \\
\text { (ppm) }\end{array}$} & \multicolumn{2}{|c|}{$\mathrm{pH}$} & \multicolumn{2}{|c|}{ EC } & \multicolumn{2}{|c|}{ N mgkg } & \multicolumn{2}{|c|}{ P ${ }^{\mathrm{mgkg}}$} & \multicolumn{2}{|c|}{$\mathrm{K}^{\prime} \mathrm{mgg}^{-1}$} & \multicolumn{2}{|c|}{ B mgkg } & \multicolumn{2}{|c|}{ Si mgkg } & \multicolumn{2}{|c|}{ Zn mgkg } \\
\hline & & & 8.03 & 8.02 & 5.73 & 5.60 & 35.80 & $\begin{array}{r}2 \\
37.20\end{array}$ & 2.86 & $\begin{array}{l}2 \\
2.90\end{array}$ & & \begin{tabular}{|c}
$\mathbf{2}$ \\
195.12
\end{tabular} & $\frac{1}{0.86}$ & $\begin{array}{l}\mathbf{2} \\
089\end{array}$ & $\frac{1}{1690}$ & $\frac{2}{1700}$ & $\frac{1}{069}$ & $\begin{array}{l}\mathbf{2} \\
0.71\end{array}$ \\
\hline \multirow{7}{*}{ Without } & & 50 & 8.02 & 8.01 & 5.61 & 5.32 & 39.40 & 41.00 & 2.94 & 2.97 & \begin{tabular}{|l|}
50.197 .12 \\
\end{tabular} & $\frac{190.1<}{199.31}$ & 0.88 & 0.91 & \begin{tabular}{|l|l|}
17.50 \\
\end{tabular} & 17.60 & 0.72 & 0.74 \\
\hline & Si & 100 & 8.01 & 8.00 & 5.55 & 5.46 & 42.60 & 45.00 & 2.98 & 3.01 & 201.21 & 204.11 & 0.91 & 0.94 & 17.60 & 17.80 & 0.74 & 0.76 \\
\hline & & 150 & 8.00 & 7.99 & 5.30 & 5.25 & 46.10 & 47.90 & 3.02 & 3.04 & & & 0.93 & & & & & \\
\hline & & 0 & 8.04 & 8.03 & 5.86 & 5.82 & 38.10 & 40.00 & 2.72 & 2.75 & 190.1 & 194.20 & 0.88 & 0.92 & 16.20 & 16.40 & 0.63 & 0.66 \\
\hline & B & 25 & 8.03 & 8.02 & 5.74 & 5.69 & 40.50 & 41.20 & 2.78 & 2.81 & 195.15 & 197.03 & 0.91 & 0.93 & 16.30 & 16.50 & 0.67 & 0.69 \\
\hline & $B$ & 50 & 8.03 & 8.01 & 5.72 & 5.58 & 42.80 & 43.10 & 2.80 & 2.83 & 198.11 & 202.05 & 0.93 & 0.96 & 16.50 & 16.70 & 0.69 & 0.72 \\
\hline & & 100 & 8.02 & 8.00 & 5.63 & 5.54 & 45.90 & 46.00 & 2.85 & 2.87 & 200.21 & 204.10 & 0.94 & 0.97 & 16.70 & & 0.72 & \\
\hline \multirow{8}{*}{ With } & \multirow{4}{*}{ Si } & 0 & 8.02 & 8.01 & 5.20 & 4.93 & 38.40 & 41.60 & 3.01 & 3.03 & 198.31 & 201.12 & 0.88 & 0.93 & 18.00 & & 0.72 & 0.74 \\
\hline & & 50 & 8.00 & 8.00 & 4.86 & 4.72 & 42.10 & 44.20 & 3.05 & 3.08 & 204.35 & 206.22 & 0.91 & 0.95 & 18.70 & 18.80 & 0.75 & 0.76 \\
\hline & & 100 & 7.99 & 7.98 & 4.66 & 4.39 & 48.50 & 51.70 & 3.07 & 3.10 & 207.16 & 209.41 & 0.93 & 0.97 & 18.90 & 18.10 & 0.77 & 0.79 \\
\hline & & 150 & 7.97 & 7.95 & 4.52 & 4.30 & 50.90 & 52.10 & 3.05 & 3.14 & 209.21 & 213.13 & 0.95 & 0.99 & 19.00 & 19.30 & 0.79 & 81 \\
\hline & & 0 & 8.03 & 8.02 & 5.42 & 5.30 & 38.30 & 40.90 & 2.94 & 2.96 & 195. & 198.16 & 0.96 & 0.99 & 17.80 & 18.30 & 0.70 & 0.72 \\
\hline & B & 25 & 8.02 & 8.00 & 5.14 & 4.98 & 41.90 & 42.00 & & 2.99 & & & 0.98 & & & & & \\
\hline & & 50 & 8.00 & 7.99 & 4.97 & 4.88 & 46.40 & 47.30 & 2.98 & 3.02 & 201.11 & 205.21 & 1.01 & 1.04 & 8.50 & & 0.76 & \\
\hline & & 100 & 8.00 & 7.98 & 4.89 & 4.76 & 48.30 & 50.10 & 3.01 & 3.05 & 206.12 & 208.22 & 1.03 & 1.06 & 18.70 & 18.90 & 0.79 & 0.80 \\
\hline Nithout & -- & -- & 8.02 & 8.01 & 5.64 & 5.53 & 41.40 & 42.68 & 2.87 & 2.90 & 197.64 & 200.27 & 0.91 & 0.94 & 16.94 & 17.09 & 0.70 & 0.73 \\
\hline With & --- & --- & 8.00 & 7.99 & 4.96 & 4.78 & 44.35 & 46.24 & 3.01 & 3.05 & 202.45 & 205.46 & 0.96 & 0.99 & 18.48 & 18.60 & 0.75 & 0.77 \\
\hline & Si & --- & 8.01 & 8.00 & 5.18 & 5.00 & 42.98 & 45.09 & 3.00 & 3.03 & 202.07 & 204.33 & 0.91 & 0.94 & 18.05 & 18.09 & 0.74 & 0.76 \\
\hline & $B$ & --- & 8.02 & 8.01 & 5.42 & 5.32 & 42.78 & 43.83 & 2.88 & 2.91 & 198.02 & 201.39 & 0.96 & 0.99 & \begin{tabular}{|l}
77.36 \\
\end{tabular} & 17.60 & 0.71 & 0.73 \\
\hline Without & Si & --- & 8.02 & 8.01 & 5.55 & 5.41 & 40.98 & 42. & 2.9 & 2.98 & 199.39 & 201.19 & 0.90 & 0.9 & 17.45 & \begin{tabular}{|l|l}
7.58 \\
\end{tabular} & 0.73 & \\
\hline Without & $B$ & -- & 8.03 & 8.02 & 5.74 & 5.66 & 41.83 & 42.58 & 2.79 & 2.82 & 195.90 & 199.35 & 0.92 & 0.0 & $\begin{array}{l}16.43 \\
\end{array}$ & 16.60 & 0.68 & \\
\hline With & $\overline{\mathrm{Si}}$ & --- & 8.00 & 7.99 & 4.81 & 4.59 & 44.98 & 47.40 & 3.0 & 3.09 & 204.76 & 207.47 & 0.92 & 0.96 & 18.65 & & 0.76 & 0.78 \\
\hline With & $B$ & -- & 8.01 & 8.00 & 5.11 & 4.98 & 43.73 & 45.08 & 2.8 & 3.01 & 200.14 & & 1.00 & 1.0 & 18.30 & & 0.75 & \\
\hline--- & -- & 0 & 8.03 & 8.02 & 5.55 & 5.41 & 37.65 & 39.93 & 2. & 2.91 & 194.18 & & 0.9 & 0. & 17.23 & & 0.69 & \\
\hline--- & --- & 50 & 8.02 & 8.01 & 5.34 & 5.18 & 40.98 & 42.10 & 2.93 & 2.96 & 198.70 & 201.19 & 0.92 & 0.95 & 17.68 & 17.85 & 0.72 & 0.74 \\
\hline--- & -- & 100 & 8.01 & 8.00 & 5.23 & 5.08 & 45.08 & 46.78 & 2.9 & 2.99 & 201.90 & 205.20 & 0.95 & 0.98 & 17.88 & \begin{tabular}{|l|l|}
17.83 \\
\end{tabular} & 0.74 & 0.76 \\
\hline--- & -- & 150 & 8.00 & 7.98 & 5.09 & 4.96 & 47.80 & 49.03 & 2.9 & 3.03 & 205.41 & 207.92 & 0.96 & 1.00 & 18.05 & 18.23 & 0.76 & 0.79 \\
\hline Without & --- & 0 & 8.04 & 8.03 & 5.80 & 5.71 & 36.95 & 38.60 & 2.7 & 2.83 & 191.62 & 194.66 & 0.87 & 0.9 & 16.55 & 16 & 0.66 & 0 \\
\hline Without & --- & 50 & 8.03 & 8.02 & 5.68 & 5.51 & 39.95 & 41.10 & 2.8 & 2.89 & 196.14 & 198.17 & 0.90 & 0.9 & 16.90 & & & \\
\hline Without & --- & 100 & 8.02 & 8.01 & 5.64 & 5.52 & 42.70 & 44. & 2.8 & 2.9 & 199. & & 0.9 & & \begin{tabular}{|l|l}
17.05 \\
\end{tabular} & & 0.72 & 0.74 \\
\hline Without & --- & 150 & 8.01 & 8.00 & 5.47 & 5.40 & 46.00 & & 2.5 & 2.9 & 203 & & 0.94 & & 17.25 & & 0.74 & 0.77 \\
\hline With & --- & 0 & 8.03 & 8.02 & 5.31 & 5.12 & 38.35 & 41.25 & 2.9 & 3.00 & 196.73 & & 0.92 & 0.96 & 17.90 & & 0.71 & 0.73 \\
\hline With & --- & 50 & 8.01 & 8.00 & 5.00 & 4.85 & 42.00 & 43. & 3.8 & 3.0 & & & 0.9 & & 18.45 & & 0.74 & \\
\hline ith & --- & 100 & 8.0 & & & & & & & & & & & & & & 0.77 & \\
\hline With & -- & 150 & 7.99 & 7. & 4.71 & 4.53 & 49 & 51 & 3. & 3. & 207 & 2 & 0.9 & 1. & 18 & 0 & 0.79 & \\
\hline$\cdots$ & Si & 0 & 8.03 & $8 .($ & 5.47 & 5. & 37 & & 2. & 2. & & & 0.8 & 0. & 17.45 & & 0.71 & \\
\hline$\ldots$ & Si & 50 & 8.01 & 8.01 & 5.24 & 5. & & & 3. & $3 .(1$ & & & 0. & & & & 0.74 & \\
\hline--- & Si & 100 & 8.00 & 7. & 5. & 4.93 & & & 3. & 3. & 20 & 20 & 0. & & & & 0.76 & \\
\hline--- & Si & 150 & 7.99 & 7. & & 4.78 & & & & & & 209 & & & & & & \\
\hline--- & $\bar{B}$ & 0 & 8.04 & 8.03 & 5.6 & 5.56 & 38.20 & 40. & & & 192 & & 0.9 & & 17.00 & & 0.67 & 0.69 \\
\hline--- & B & 25 & 8.03 & 8.01 & 5.44 & 5.34 & 41.20 & 41. & 2.8 & 2.9 & 196 & & 0.95 & 0. & $\begin{array}{l}17.25 \\
\end{array}$ & 17.50 & 0.70 & 0.72 \\
\hline--- & B & 50 & 8.02 & 8.00 & 5.35 & 5.23 & 44.60 & 45.20 & 2.8 & 2.93 & 199 & 203 & 0.97 & 1.0 & 17.50 & 17.70 & 0.73 & 0.75 \\
\hline$\ldots$ & B & 100 & 8.01 & 7.99 & 5.26 & 5.15 & 47.10 & 48.05 & & 2.96 & 203.17 & & 0.99 & & \begin{tabular}{|l|l}
17.70 \\
\end{tabular} & 17.85 & 0.76 & 0.78 \\
\hline & & & NS & 0.02 & 0.16 & 0.03 & 0.06 & 0.3 & 0.0 & 0.09 & 1.0 & 1.2 & 0.4 & & 0.14 & 0.28 & 0.02 & 0.10 \\
\hline & & & NS & NS & 0.16 & 0.03 & 0.06 & 0.30 & 0.0 & 0.09 & 1.0 & 1.2 & 0.0 & 0.0 & 0.14 & & 002 & \\
\hline 일 & AB & & NS & NS & NS & 0.04 & & 0.4 & & $\mathrm{~N}$ & & & & & 0. & & & \\
\hline ๑ & & & NS & 0.02 & 0.23 & 0.04 & 0. & 0.4 & 0. & $\mathrm{~N}$ & 1.4 & 1. & 0. & $\mathrm{~N}$ & 0.19 & & 0.03 & IN \\
\hline n & $\overline{A C}$ & & NS & NS & NS & 0.05 & 0.11 & 0.6 & $\mathrm{~N}$ & Ns & $\mathrm{N}$ & $\mathrm{N}$ & NS & $\mathrm{N}$ & $\mathrm{NS}$ & $\mathrm{N}$ & NS & NS \\
\hline & $B C$ & & NS & NS & NS & NS & 0.11 & 0.60 & $\mathrm{NS}$ & NS & NS & $\mathrm{N}$ & NS & NS & NS & NS & NS & NS \\
\hline & $\overline{A B C}$ & & NS & NS & NS & 0.07 & 0.16 & 0.85 & NS & NS & NS & NS & NS & NS & NS & NS & NS & NS \\
\hline
\end{tabular}


Table 4. Chemical composition of peanut (Arachis hypogaea $\mathrm{L}$ ) during two seasons after harvesting

\begin{tabular}{|c|c|c|c|c|c|c|c|c|c|c|c|c|c|c|c|c|c|c|}
\hline \multirow{2}{*}{ Compost } & \multirow{2}{*}{$\begin{array}{c}\text { sprayi } \\
\text { ng }\end{array}$} & \multirow{3}{*}{$\begin{array}{c}\text { Rate } \\
\text { (ppm) } \\
0 \\
\end{array}$} & \multicolumn{2}{|c|}{ N\% } & \multirow{2}{*}{\multicolumn{2}{|c|}{ P\% }} & \multirow{2}{*}{\multicolumn{2}{|c|}{$\mathrm{K} \%$}} & \multirow{2}{*}{\multicolumn{2}{|c|}{$\frac{8}{3} \mathrm{mgkg}$}} & \multirow{2}{*}{\multicolumn{2}{|c|}{ Si mgkg }} & \multirow{2}{*}{\multicolumn{2}{|c|}{ Zn mgkg }} & \multirow{2}{*}{\multicolumn{2}{|c|}{ Protein \% }} & \multirow{2}{*}{\multicolumn{2}{|c|}{ Oil\% }} \\
\hline & & & $\pi$ & 4 & & & & & & & & & & & & & & \\
\hline \multirow{7}{*}{ Without } & & & $\begin{array}{l}3.12 \\
3.42\end{array}$ & $\begin{array}{l}3.11 \\
3.40\end{array}$ & 0.32 & 0.29 & 2.47 & $\frac{2.50}{2.55}$ & 40 & $\frac{67.20}{7090}$ & $\begin{array}{l}12.60 \\
1430\end{array}$ & $\begin{array}{r}13.00 \\
1470\end{array}$ & 14.08 & $\frac{20.30}{2150}$ & $\begin{array}{l}19.50 \\
2.128\end{array}$ & 19.44 & 39.01 & \\
\hline & Si & 100 & 3.49 & 3.46 & 0.39 & 0.35 & 2.55 & 2.59 & & 73.70 & 17.20 & 1750 & 4.54 & 21.0 & & 21.25 & \begin{tabular}{|l}
41.10 \\
4312
\end{tabular} & $\frac{42}{44}$ \\
\hline & & 150 & 3.53 & 3.49 & 42 & & 2.58 & 2.63 & 3.6 & & & & & & & & & \\
\hline & & 0 & 3.09 & 3.12 & .28 & 0.30 & 2.30 & 2.35 & 63.20 & 59.60 & .40 & 12 & 3.11 & 16.7 & 19.31 & 19.50 & 38.13 & \\
\hline & & 25 & 3.28 & 3.34 & 0.31 & 0.33 & 2.36 & 2.39 & 68.70 & 62.30 & 14.20 & 14. & 13.45 & 18.00 & 20.50 & 20.88 & 40.25 & 41. \\
\hline & & 50 & 3.32 & 3.38 & 0.34 & 0.36 & 2.38 & 2.42 & 72.40 & 67.90 & 16.90 & 17.00 & 13.57 & 18.40 & & & 41.26 & 42. \\
\hline & & 100 & 3.35 & 3.39 & 0.37 & 0.39 & 2.41 & 2.44 & 76.00 & 68.50 & 17.30 & 17.50 & 13.74 & 18.70 & 20.94 & 21.19 & 43.19 & 44. \\
\hline \multirow{7}{*}{ With } & & & 3.18 & 310 & 0.36 & 0.39 & 2.51 & 2.53 & & 66.00 & 71 & 14 & 4.31 & 20.70 & 19.88 & 19.94 & 41.11 & \\
\hline & $\mathbf{S i}$ & 5 & 3.48 & 3.5 & 0.39 & & 2.57 & 2.59 & 67.90 & & 16. & 16 & 4.65 & 22.90 & 21.75 & 94 & 43.31 & $\frac{44.31}{46.35}$ \\
\hline & & $\begin{array}{l}100 \\
150\end{array}$ & $\begin{array}{l}3.52 \\
3.56\end{array}$ & $\begin{array}{l}3.55 \\
3.59\end{array}$ & $\begin{array}{l}0.41 \\
0.44\end{array}$ & $\begin{array}{l}0.44 \\
0.46\end{array}$ & $\begin{array}{l}2.61 \\
2.63\end{array}$ & $\begin{array}{l}2.63 \\
2.65\end{array}$ & $\begin{array}{l}69.80 \\
700.30\end{array}$ & $\begin{array}{l}70.00 \\
70.50\end{array}$ & $\frac{18.40}{19.00}$ & $\begin{array}{l}18 \\
19\end{array}$ & 4. & 23.40 & $\frac{22.00}{22.25}$ & $\begin{array}{l}22.19 \\
22.44\end{array}$ & \begin{tabular}{|l|}
44.24 \\
55.31
\end{tabular} & $\begin{array}{l}46.35 \\
47.22\end{array}$ \\
\hline & & 0 & 3.16 & 3.18 & 0.34 & 0.36 & 2.48 & 2.50 & C. & 67.50 & 12.40 & 12. & 4.14 & 20.20 & 19 & 19.88 & \begin{tabular}{|l|}
40.33 \\
\end{tabular} & \\
\hline & & ? & 3.44 & 3.47 & 0.37 & 0.39 & 2.51 & 2.54 & & 71.80 & 15.00 & 15 & 43 & 21.70 & 21.50 & 21.69 & 42.23 & \\
\hline & & 50 & 3.47 & 3.49 & 0.39 & 0.42 & 2.55 & 2.58 & 73. & 73.70 & 15 & 16 & 454 & 23.00 & 21.69 & & 44.26 & \\
\hline & & 100 & 3.50 & 3.52 & 0.41 & 0.44 & 2.58 & 2.61 & 75.00 & 75.20 & 16. & 16 & 4.71 & 23.30 & 21.88 & 22.00 & 46.11 & 47 \\
\hline no & --- & -- & 3.33 & 3.34 & 35 & 0.34 & 2.45 & 2.48 & 67.20 & 68.54 & 15 & 15 & 3.95 & 19.85 & 20.78 & 20.85 & 41.27 & \\
\hline Vith & & 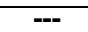 & 3.41 & 3.4 & 39 & 0.42 & 2.56 & 2.58 & & 70 & & & 57 & & 21.34 & & 43.36 & \\
\hline & $\mathbf{S}$ & --- & 3.41 & 3.41 & 39 & 0.3 & 2.5 & 2.58 & & 70 & & & & & & & & \\
\hline & B & --- & 3.33 & & & & 7 & 2.48 & & & & & & & & & & \\
\hline & $\overline{\mathbf{S i}}$ & --- & 3.35 & & 3 & & 2.5 & 2.57 & & & & & & & & & 41.84 & \\
\hline & B & -- & 0.6 & & 3 & & 2. & 2.4 & & & & & & & & & & \\
\hline & Si & --- & 3.44 & & & & 2. & 2.6 & & & & & & & & & & \\
\hline ith & B & - & & & & 0. & 2. & 2.5 & & & & & 43 & 26 & 21 & & & \\
\hline--- & - & 0 & 3. & & & 0 & 2.4 & 2.4 & & & & & & & 19 & & 39.65 & \\
\hline & - & 50 & 3.41 & & & & 2.4 & 2. & & & & & & & & & & \\
\hline & 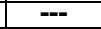 & 100 & 3.4 & & & & 2. & 2. & & & & & & & & & & \\
\hline & - & 150 & 3.4 & 3. & & & 2.5 & 2. & & & & & & & & & & \\
\hline the & & 0 & 3.1 & 3.1 & & 0. & 2. & 2. & & & & & & & & & & \\
\hline & --- & 5 & 3. & & & & 2. & 2.47 & & & & & & & & & & \\
\hline & - & $\pi$ & 3.4 & & & & 2. & 2 & & & & & & & & & & \\
\hline & -- & 15 & 3.4 & & & & & & & & & & & & & & & \\
\hline & - & 0 & & & & & & 2. & & & & & & & & & & \\
\hline & - & & & & & & & 2. & & & & & & & & & & \\
\hline & --- & & 3.50 & & & & & 2. & & & & & & & & & 44 & \\
\hline & -- & & & & & & & & & & & & & & & & & \\
\hline & Si & 0 & 3. & & & & & & & & & & & & & & & \\
\hline & Si & 5 & 3. & & & & & & & & & & & & & & & \\
\hline & Sí & 70 & 3. & & & & & & & & & & & & & & & \\
\hline-- & Sí & 150 & 3.5 & 3.5 & 0. & 0.2 & 2.6 & & & & & & & & & & 44.71 & \\
\hline- & B & 0 & 3.13 & 3.1 & & 0.3 & 2. & 2. & & & 11 & & 13 & & & & 39.23 & \\
\hline- & $\pi$ & 25 & 3.3 & 3.4 & 0. & 0 & 2.4 & 2. & & & & & & & & & & \\
\hline- & B & 50 & 3.40 & 3.4 & & & 2. & 2. & & & & & & & & & & \\
\hline--- & $\bar{B}$ & 100 & 3.43 & 3. & & & 2. & 2. & & & & & & & & & & \\
\hline & & & & NS & & 0. & 0. & $\mathrm{~N}$ & & & & & & & & & & \\
\hline & & & & $\mathrm{N}$ & & & 0. & 0. & & & & & & & & & & \\
\hline o. & & & & & & & $\mathrm{N}$ & $\mathrm{N}$ & & & & & & & & & & \\
\hline & & & & 0.15 & 0.02 & 0. & $N_{5}$ & $\mathrm{~N}$ & & $\pi$ & 0. & & 0.7 & 0. & 0. & 0. & 0.60 & \\
\hline & $\overline{A C}$ & & & NS & NS & $\mathrm{N}$ & NS & NS & & $\mathrm{N}$ & & & $\mathrm{N}$ & $\mathrm{N}$ & $\mathrm{Ns}$ & & NS & \\
\hline & & & & NS & NS & NS & NS & NS & \begin{tabular}{|l|l|} 
\\
\end{tabular} & NS & NS & 0.60 & NS & NS & 0.27 & NS & NS & ת \\
\hline
\end{tabular}


Table 5. Yield and yield compounds as well as Chlorophyll

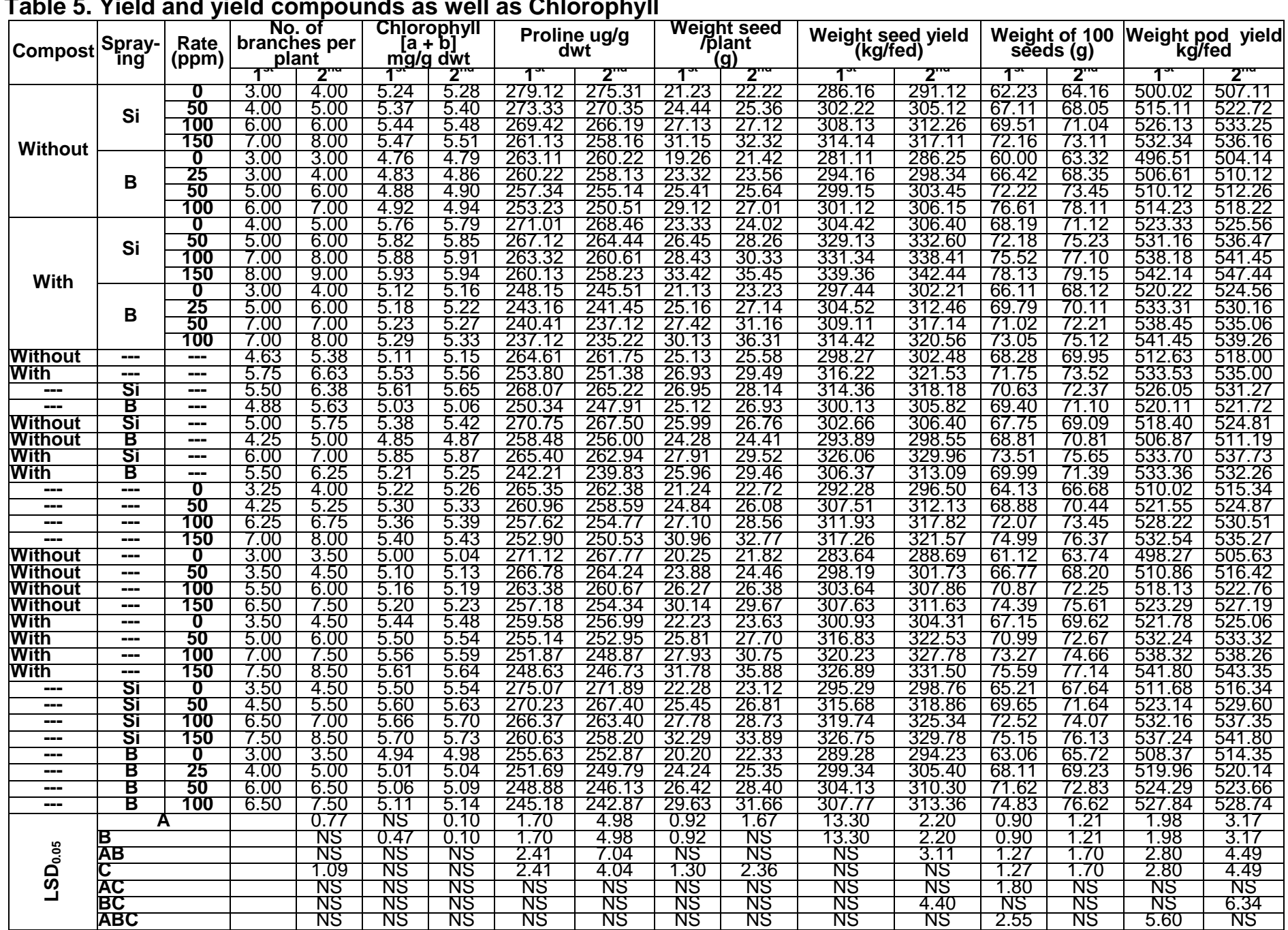


Shaban, Kh. A. H. et al 